\title{
SERIES
}

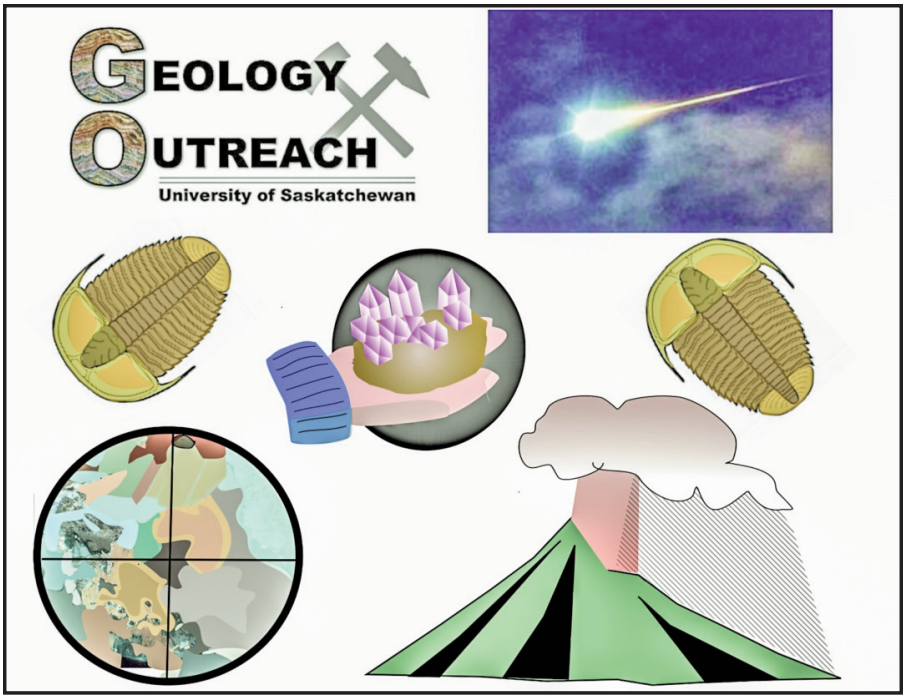

Earth Science Education 6.

\section{Lessons Learned: Organizing a Geoscience Outreach Program at the University of Saskatchewan}

\section{Courtney Onstad}

Department of Earth Sciences, Simon Fraser University

8888 University Drive, Burnaby, British Columbia

V5A 1S6, Canada

E-mail: courtney_onstad@sfu.ca

\section{SUMMARY}

Geology Outreach at the University of Saskatchewan was initiated during the 2018/19 academic year as a free and informal education opportunity for $\mathrm{K}-12$ educators and their students in Saskatchewan. The program was 100\% volunteer-run by undergraduate and graduate students in the Department of Geological Sciences at the University of Saskatchewan. We estimate reaching more than 1000 students in Saskatoon and surrounding areas following two years of outreach offerings. Hands-on activities offered included 'Rocks and Minerals', 'Fossils', 'Meteorite Impacts' and 'Volcanoes' and also involved a tour of the Museum of Natural Sciences when completed on campus. The overall intent of these activities was to foster excitement about the Earth Sciences. Typically, Educators who booked our program taught grades 4-7, where the Earth Sciences are strongly represented in Saskatchewan's science curriculum. Most outreach offerings occurred on the University of Saskatchewan campus, but some were offered remotely at elementary schools and various Girl Guides of Canada events. During the 2019/20 academic year, we booked every outreach event planned for that year within two days and had a waiting list of more than 30 teachers across the province. The demand for geoscience outreach in Saskatchewan is high, and we hope to continue providing engaging, relevant, and fun educational outreach opportunities. University departments across Canada should allocate funds for community and school outreach initiatives and hire science communicators to oversee programs such as this.

\section{RÉSUMÉ}

Le programme «Geology Outreach » de l'Université de la Saskatchewan a débuté au cours de l'année universitaire 2018/19 en tant qu'opportunité d'éducation gratuite et informelle pour les éducateurs de la maternelle à la 12e année et leurs étudiants en Saskatchewan. Le programme était géré à 100\% par des étudiants bénévoles de premier cycle et des cycles supérieurs du Département des sciences géologiques de l'Université de la Saskatchewan. Nous estimons atteindre plus de 1000 étudiants à Saskatoon et dans les régions voisines après deux années d'offres de sensibilisation. Les sujets des activités pratiques proposées comprenaient « Roches et minéraux », « Fossiles », «Impacts de météorites » et « Volcans », et impliquaient également une visite du Musée des sciences naturelles quand les activités étaient proposées sur le campus. L'objectif général de ces activités était de susciter de l'enthousiasme pour les sciences de la Terre. En règle générale, les éducateurs qui ont fait la demande de notre programme enseignaient aux élèves de la 4 e à la 7 e année, où les sciences de la Terre sont fortement représentées dans le programme des sciences de la Saskatchewan. La plupart des activités de sensibilisation ont eu lieu sur le campus de l'Université de la Saskatchewan, mais certaines ont été offertes à distance dans les écoles élémentaires et lors de divers événements des Guides du Canada. Au cours de l'année scolaire 2019/20, toutes les offres de sensibilisation pour cette année ont été réservées en deux jours et nous avions une liste d'attente de plus de 30 enseignants à travers la province. La demande de sensibilisation géoscientifique en Saskatchewan est élevée, et nous espérons continuer à offrir des opportunités de sensibilisation 
éducative engageantes, pertinentes et amusantes. Les départements universitaires à travers le Canada devraient allouer des fonds aux initiatives de sensibilisation communautaire et scolaire et embaucher des communicateurs scientifiques pour superviser des programmes comme celui-ci.

Traduit par la Traductrice

\section{INTRODUCTION}

In Saskatchewan's science curriculum, the Earth Sciences are well represented in grades 1 through 10 (Government of Saskatchewan 2021). Unfortunately, Earth Science topics are often skipped over or taught primarily from worksheets and textbooks. Classrooms may not have access to resources and materials to demonstrate Earth Science processes or concepts effectively, and many teachers do not have a background in Earth Sciences. Thus, creating additional geoscience-related educational resources for educators is a practical approach to supplement classroom learning.

During a summer job with the University of Saskatchewan (U of S), through the College of Arts and Science's "Science Ambassador Program", I was assigned to the small northern community of Île-à-la-Crosse, Saskatchewan. While working in this community, I had the opportunity to give presentations and design hands-on experiments for $\mathrm{K}-12$ students focusing on the Earth Sciences. These lessons included volcanology, rocks and minerals, fossils, erosional features, plate tectonics and earthquakes. There were also outdoor field activities where we explored local boulders featuring volcanic and plutonic rocks from the Precambrian shield. The students' amazement that $\sim 1.8$ billion years ago they would have been standing amongst volcanoes stuck with me and initiated my desire to start a formal outreach program at the University of Saskatchewan.

At the time, I was a graduate student in the Department of Geological Sciences at the University of Saskatchewan. I was well aware of the educational resources available within the department. Common to all university Earth Science departments, $\mathrm{U}$ of $\mathrm{S}$ has an excellent collection of rocks, minerals, and fossils from across the world. The U of S Museum of Natural Sciences provided a perfect opportunity for guided tours of the various displays, exhibits, and informative signage. Diverse rock and mineral samples, a space for activities and/or tours, expertise on the material, and students' willingness to help were necessary factors to initiate the outreach program. This paper reviews the initial planning, the outreach offerings, and the feedback received. It then takes a closer look at the lessons learned, benefits to those involved, and makes suggestions for future outreach initiatives.

\section{INITIAL PLANNING}

\section{Points to Consider}

Before initiating the outreach program, extensive planning was necessary to ensure that students and teachers had an enjoyable, organized, and meaningful experience. Some of the details addressed in planning include:
1. Funding to acquire supplies for hands-on experiments.

2. Personnel to present, answer questions, set up materials and clean up after a session (typically 2-4 people).

3. Determine the most effective approaches for communicating with students.

4. Develop content that would align hands-on activities with the 'Earth and Space Science' component of Saskatchewan's K-9 science curriculum

5. Ensure appropriate media platforms for communication with educators and a space to organize materials after booking an event.

\section{Funding}

The financial support received by the Canadian Geological Foundation (2021), TakingITGlobal (2021), and the U of S Department of Geological Sciences enabled this outreach program's success. The funding was used to have eight microscope transport cases made (Fig. 1) and to purchase supplies for hands-on activities. In-kind funding from the Department of Geological Sciences allowed for use of the departmental truck and coverage of operating expenses for outreach trips to schools and communities that could not travel to the $\mathrm{U}$ of $\mathrm{S}$.

\section{Modes for Communicating}

Various methods have been proposed for communicating in outreach settings including the three prominent models for science communication (deficit, dialogue, and participation models; Metcalfe 2019). Among many issues (e.g. it assumes supremacy of western knowledge) the deficit model utilizes a one-way, top-down transmission of information from the presenter (expert) to the audience (layperson). This assumes that by audiences gaining more knowledge, they will inevitably have a positive attitude towards the topic (Reincke et al. 2020). The dialogue model is a form of two-way communication involving a transfer of information between presenter and layperson and vice-versa. It builds on mutual respect, encourages listening and learning, with the audience as a helpful resource and the expert as the facilitator (Reincke et al. 2020). Lastly, the par-

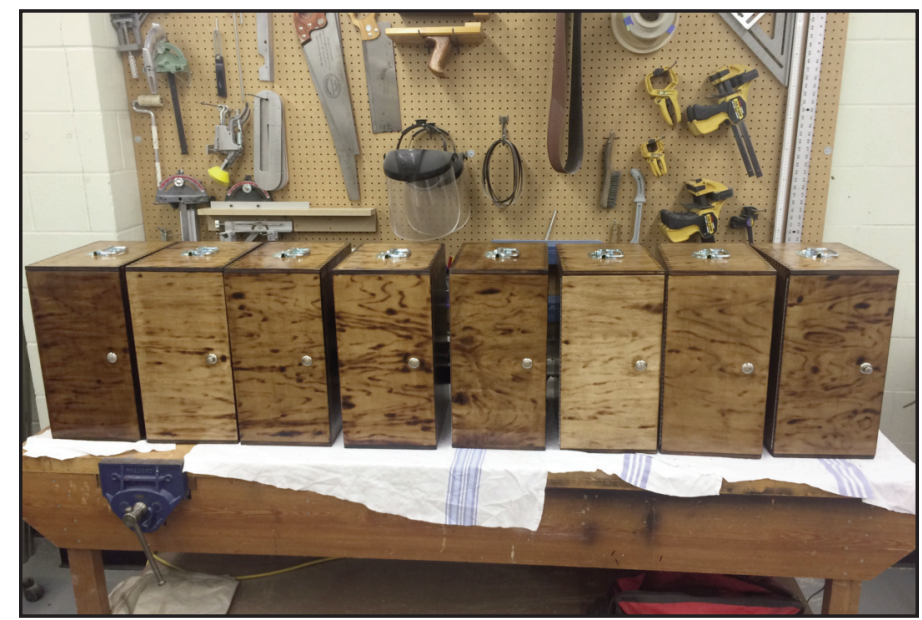

Figure 1. Transport cases for petrographic microscopes used for remote outreach activities. 
ticipation model uses multidirectional communication through engagement rather than the transmission of information. Audiences take on an active role and are considered co-creators alongside the expert (Metcalfe 2019).

Considering this outreach offering was solely organized and run by volunteers with no formal science communication training, there was no knowledge on the various approaches for communication. Thus, no specific communication goals were established early on; key for effective science communication. Nevertheless, through trial and error during the first year, it was noted that the dialogue model in combination with the deficit model was best-suited to our situation.

\section{Volunteers}

An information session (with free pizza) was hosted to gauge initial interest in the outreach program and recruit volunteers. This event gave students a sense of the activities to be taught, how participating would advance their science communication skills, and the significant experiential opportunities they would be providing for youth and teachers attending. As a result, there were 18 and 19 graduate and undergraduate student volunteers during the first and second years, respectively. Students had a range of roles during the events, including presenting, answering students' questions, running tours through the museum, and setting up and removing materials.

\section{Designing and Organizing Hands-On Activities}

Activities were designed using existing lessons and activity ideas. Developing relationships with others working in the geoscience education space was influential in developing new outreach activities. Online educational resources from organizations such as Mining Matters, the Saskatchewan Mining Association, and Impact Earth from Western University were also used. There were opportunities for student volunteers to express ideas and create lessons as well.

\section{Promotion and Booking}

A landing page for the outreach program was added to the department website with information regarding what would be expected during an outreach event. The website linked to a SurveyMonkey ${ }^{\circledR}$ form where interested teachers could indicate what activity topics they wanted, the preferred dates, provide some details about their class, and establish contact information.

A Facebook page and a Twitter account were also created to spread awareness and update the community about our outreach program. Initially, targeted Facebook advertisements were used to spread the word about our program through the Saskatchewan education community. This approach proved very effective and resulted in all outreach sessions for the entire school year becoming booked in two days (more than 20 sessions). More than 30 teachers remained interested in participation after all slots were filled and they were added to a waiting list. This demand demonstrates how sought-after geoscience outreach activities are in Saskatchewan.

\section{OUTREACH PROGRAMMING}

\section{Hands-on Activities}

Rock and Mineral Lesson: This lesson involved a 10 to 20minute presentation (approximately) with accompanying hands-on activities. The first component focused on minerals, with each slide discussing a specific mineral property (e.g. colour, lustre, hardness) used for identification. Minerals were pre-organized in groups to specifically bring students' attention to the property being discussed. For example, after presenting the slide on specific gravity, we passed out galena (heavy) and talc (light) samples together to show the notable difference.

Following this activity, we looked at minerals under a microscope. Before starting, to ensure that the students handled the microscopes carefully, presenters told students that each microscope was worth $\$ 1,000,000$; this exaggeration was justified in emphasizing that students should use extra caution! This was the student's first time seeing rocks under a microscope (Fig. 2), so no advanced observations were made. Instead, a volunteer switched between cross-polarized and plane-polarized light and sometimes inserted the gypsum plate, to get students' attention!

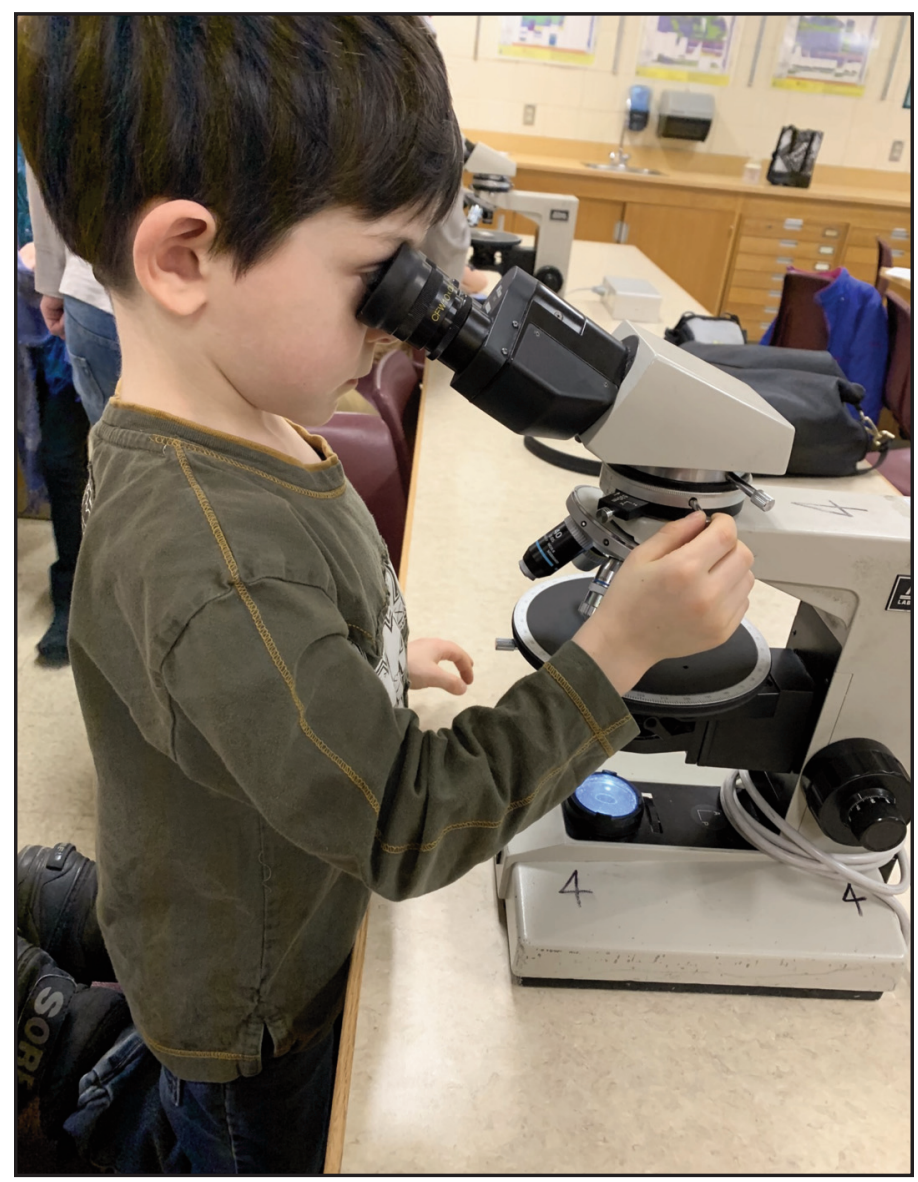

Figure 2. Homeschool student observing minerals under a petrographic microscope. 
Next, we discussed rocks and introduced the three rock types, how they formed, and how to identify them. Similar to the mineral activity, groups of rocks were distributed to students. Each group of rocks would have a sedimentary, metamorphic, intrusive, and extrusive rock. Students worked together to identify the rocks, while volunteers worked with groups to discuss their observations.

A 'mineral matching' activity from Mining Matters was excellent for getting students thinking about the importance of minerals in their everyday lives. First, students were organized into groups, each with ten mineral cards (describing the properties of a specific mineral), ten corresponding mineral samples, and ten objects that these minerals are used to make. Then, students worked together to match each mineral to the item that the mineral is used to produce.

Fossil Lesson: This lesson started with a 10-minute presentation about fossils and dinosaurs. The hands-on component involved analyzing fossils from the department's collection and included a station where students could look at fossils in 3D. Students used a camera to scan fossil cards using an iPad app, "WyoFossil", created at the University of Wyoming Geological Museum (2021). A 3D image was produced of what that fossil or animal would have looked like in real life. While this activity was in progress, two volunteers would be preparing the 'fossil dig' activity. Small plastic bowls $(\sim 12 \mathrm{~cm}$ diameter) were half-filled with sand. One volunteer would make the cast mix, which used Plaster of Paris and water. A sand-filled plastic bowl and plastic fossil molds (purchased online) were provided, and students pressed their mold into the sand, creating a compression. With volunteers' assistance, students poured the Plaster of Paris mixture into their bowls to set.

While the fossil casts dried, the lesson was broken up with a museum tour (discussed below). While students were on the tour, volunteers flipped the fossil casts onto newspaper with the sand now covering the top of the casts. When students returned, they were given a toothbrush and dental pick to carefully remove excess sand until they could extract their fossil (Fig. 3). Students were thrilled and even got to take their fossils home to show their parents!

Meteorite Impact Lesson: Students were given a quick ( $5 \mathrm{~min}$ ) presentation on meteorites and meteorite impacts. Dr. Mel Stauffer kindly loaned meteorite specimens from his collection to use for the outreach program, including iron meteorites (the Toluca, Campo del Cielo, and Canyon Diablo meteorites) and a stone meteorite. These samples were carefully passed around under supervision by volunteers for 5-10 minutes. While samples were passed around, one volunteer set up the hands-on experiment, which demonstrates how a meteorite impact occurs. The volunteer used a clear plastic container and poured a layer of flour ( $3 \mathrm{~cm}$ thick), and sifted a thin layer of cocoa powder ( $\sim 2 \mathrm{~cm}$ thick) on top. Next, a student volunteer was asked to throw a small rubber ball at the cocoa powder in the container creating an impact crater (Fig. 4a). Students used their observational skills to draw the crater's shape and discussed what factors could change it. Finally, a new volunteer threw the ball with a change in the angle, height, or speed (Fig. 4b).

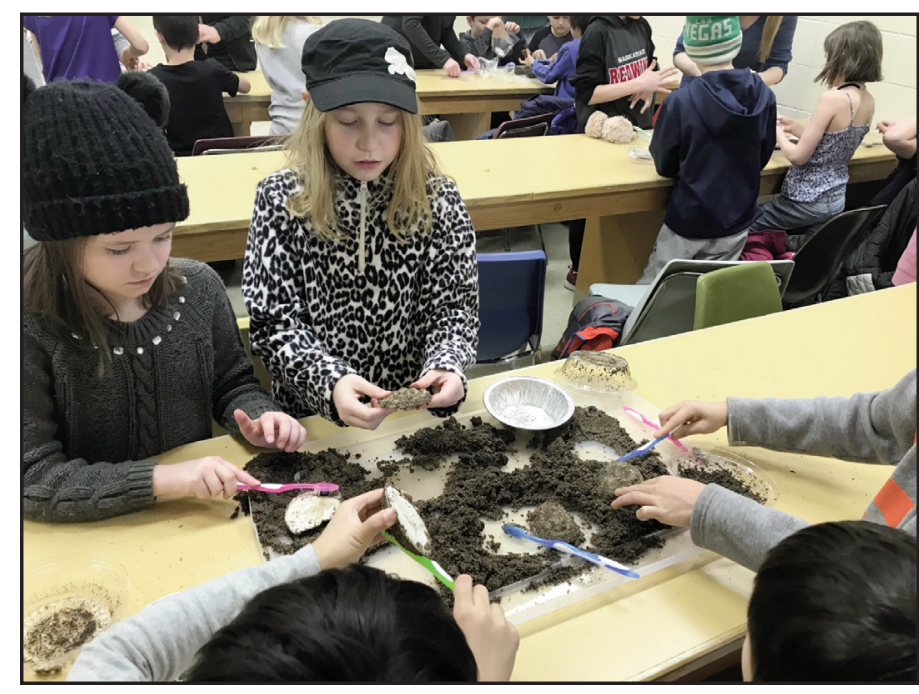

Figure 3. Students carefully using toothbrushes to uncover their fossil casts.

Volcanoes Lesson: This lesson included a $\sim 10$-minute presentation on the types of volcanoes and volcanic eruptions, combined with a hands-on component analyzing volcanic and intrusive rock samples. Students then went outside to an area where a volunteer had a small pile of ammonium dichromate on tinfoil. Students were asked to keep a 2-metre distance from the 'volcano' for safety reasons. The ammonium dichromate was lit with a match, and students watched as the exothermic reaction simulated a volcanic eruption and a cinder cone formation. The final component of this lesson involved 3 hours of preparation, with a volunteer making a bowl of gelatin. Once the gelatin was set (in a volcano shape), it was transferred on a pegboard, elevated by two bricks. A magma solution was created from red food colouring and water and was added to a syringe. A volunteer then injected 'magma' into the gelatin volcano by inserting the syringe upwards through a hole in the pegboard.

Museum Tour: The museum tour was often referred to as the highlight of a student's trip to the University. This success is attributed to volunteers' tremendous science communication skills, especially Drake Meili (aka Drake the Geologist), Simran Kharal, and Iliajah Pidskalny. Drake typically started the tour by asking students a question about something they'd learned that day. Whoever answered correctly became Drake's 'Assistant Geologist' for the day and involved wearing his prospector hat (Fig. 5) for the rest of the tour. During the tour, students saw the pristine mineral specimens and rock samples in display cases, the animals in the museum (Fig. 6), and the fossils in the Tyndall stone walls.

At the end of each of the above lessons, students were given a 'Certified Junior Geologist', 'Certified Junior Paleontologist', 'Certified Junior Meteorite Expert', or 'Certified Junior Volcanologist' button (Fig. 7) to take home with them!

\section{A Typical Outreach Day}

On the day of an outreach event, this was the typical sequence of events before, during, and after students arrived. The setup was relatively straightforward if the event was taking place on 

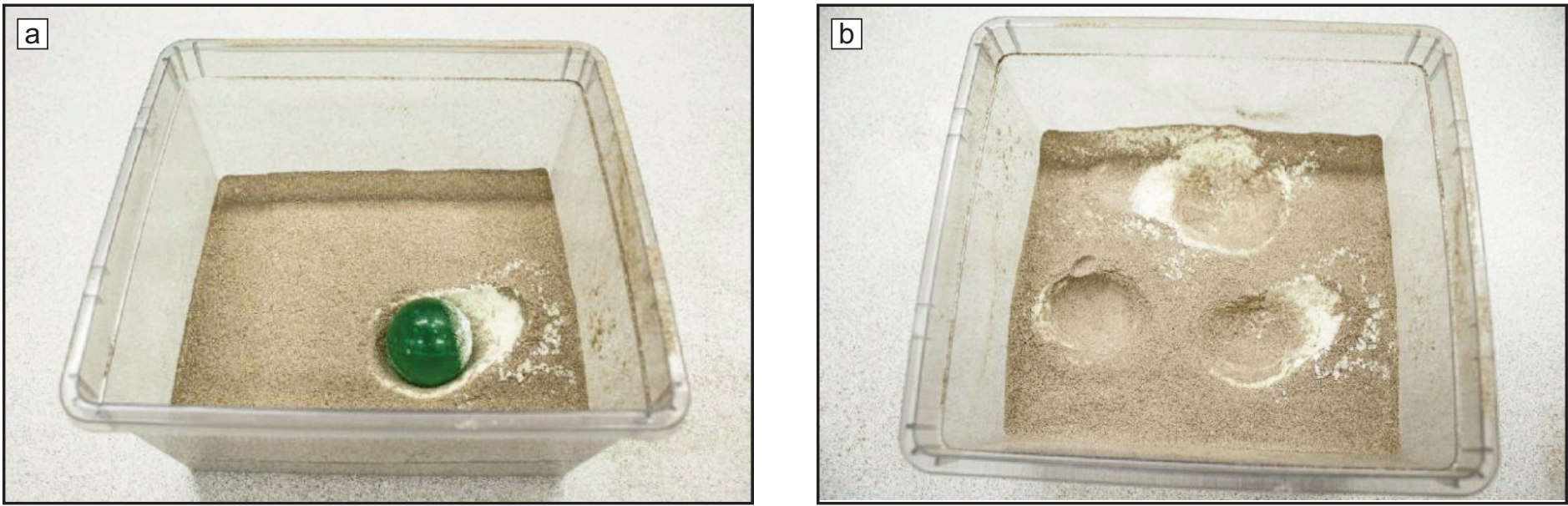

Figure 4. Meteorite impact structure(s) resulting from a rubber ball toss (a) and tosses thrown from varying angles and velocities (b).

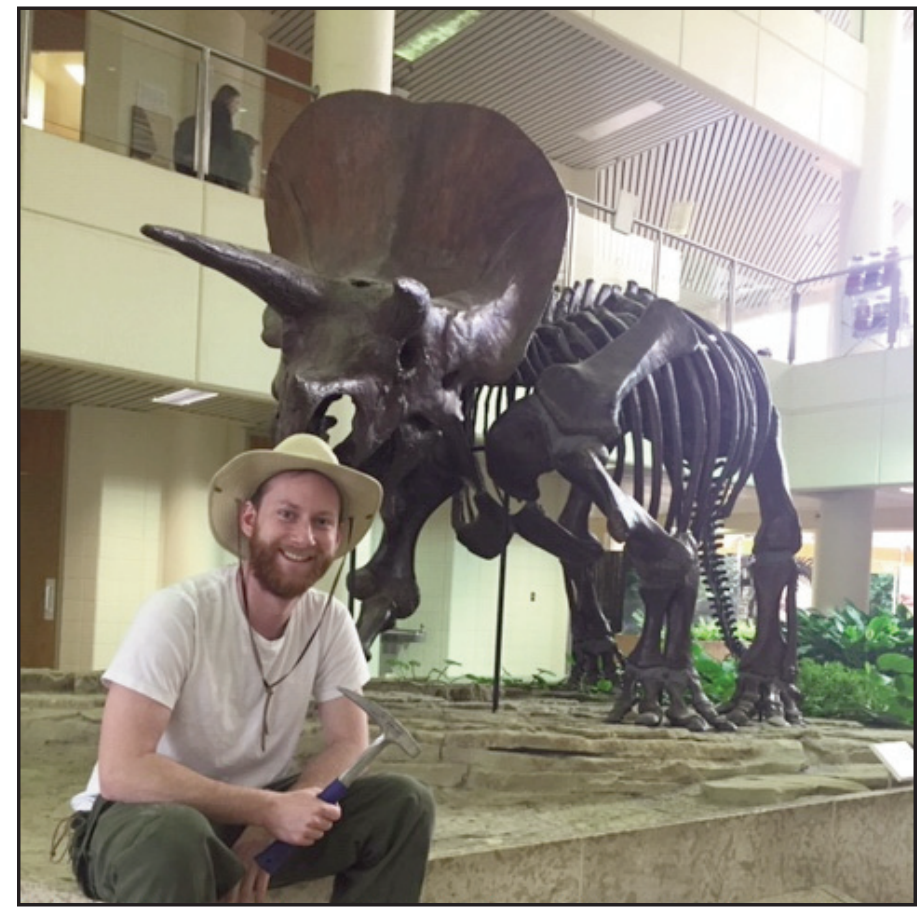

Figure 5. Geology Outreach University of Saskatchewan volunteer Drake Meili (Drake the Geologist) in his outreach attire.

campus as the classroom already had rock, mineral, and fossil samples organized from a previous session. Thirty minutes before the event, volunteers arrived to set up the equipment and materials needed and ensured that all technology worked. Once the class arrived, we completed one or two of the lessons described above, typically over two hours. When the class left, volunteers assisted with clean-up and ensured that all samples were organized to be ready for the next event. Typical post-outreach tasks involved compiling survey results following the event, returning supplies to storage, and making social media posts to promote the event.

When we were asked to travel to a school during an offcampus trip, more organization before the event was required. Volunteers typically arrived one to two hours ahead of time to

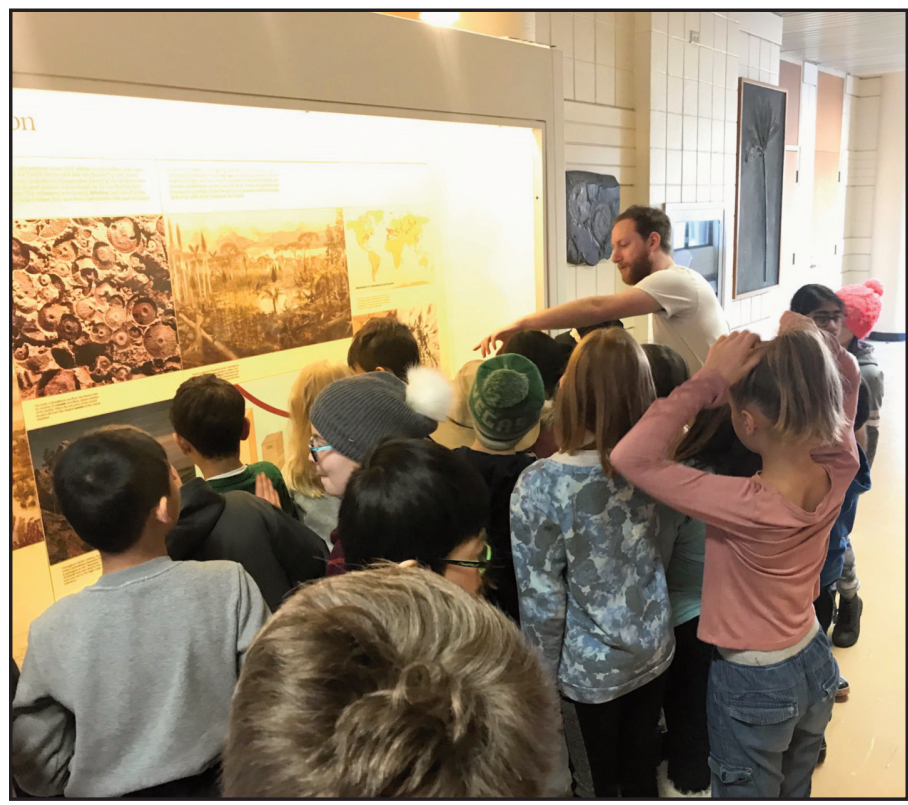

Figure 6. Drake Meili leading the museum tour for Grade 5 students in the Museum of Natural Sciences at the University of Saskatchewan.

gather all materials needed for the hands-on activities, loaded microscopes into transport cases, organized worksheets, and loaded everything into the U of S departmental truck. Typically, two or three volunteers led these off-campus events. Upon arriving at the school, volunteers checked in at the front office and were directed to a classroom. Because the supplies were previously organized at the University, minimal setup was needed. After completing the activities, volunteers packed up, brought the supplies back to the University campus, and returned them to storage.

\section{Feedback from Surveys}

To determine the effectiveness, enjoyment, and areas for improvement of our outreach activities, we provided post-outreach surveys for a sample of students and teachers. These surveys were done in late March 2020 before the COVID-19 pandemic and included 63 Grade 4 students who completed the 


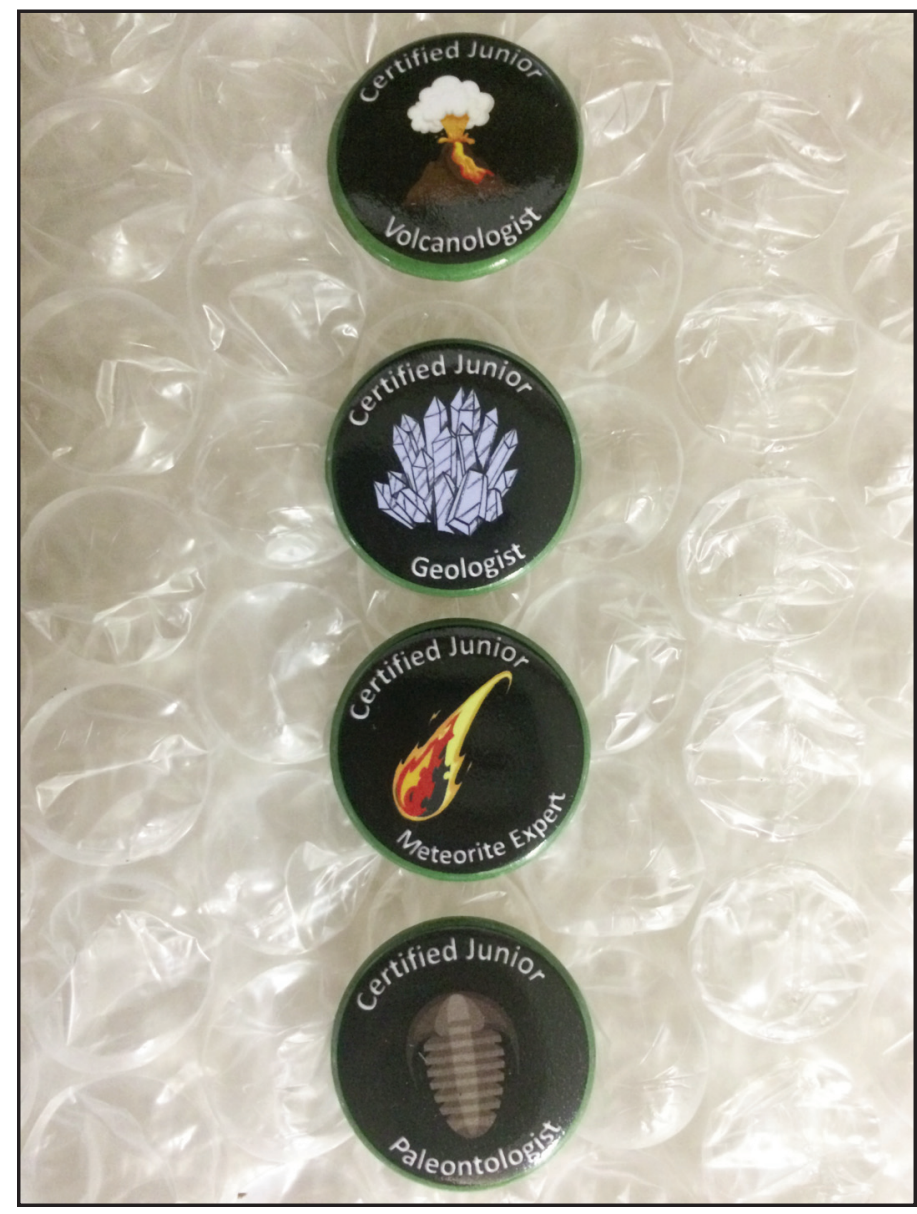

Figure 7. Badges distributed to students who completed our 'Rocks and Minerals', 'Fossils', 'Volcanoes', and 'Meteorite Impact' lessons.

'Rocks and Minerals' activity. Based on their answers, the percentages of students who enjoyed particular components most were as follows: $50 \%$ of students enjoyed the museum tour, $30 \%$ liked looking at samples under the microscope, 10\% enjoyed looking at rock and mineral hand samples, whereas 5\% enjoyed the mineral matching activity and 5\% couldn't decide and enjoyed everything. When asked what they learned, here are some typical responses:

\section{"It's important to know Earth's history." \\ "T learned that we need minerals to survive." \\ "Without rocks, we wouldn't be here, and neither would the uni- versity or the tires on our cars." \\ "I learned that minerals make our world a better world."}

When asked if they would recommend the program to colleagues, teachers also noted:

"Of course, hope to come again?" and

"Yes, it was a great way to get students out and learning, and it was a lot of fun."

\section{REVIEW AND RECOMMENDATIONS}

\section{Lessons Learned}

After two years of running Geology Outreach at the U of S, lessons learned from the successes and setbacks are summarized below:

1. It worked best with less lecturing and more hands-on activities - Geology is tactile. We should use this to our advantage and promote hands-on learning with discussion, rather than solely lecturing about geological concepts. We found the most success by lecturing in short segments (1-minute maximum) and breaking this up by allowing students to see or touch something.

2. The 'dialogue model' (Reincke et al. 2020) proved to be the most appropriate for presenting in our unique situation $(100 \%$ volunteer-run; explained in "Modes for Communicating"). This model allows presenters to use a 'conversation style' approach to communicating where volunteers and students can ask one another questions, explain reasonings for proposed answers, and engage in a way that lecturing does not permit.

3. Activities should be no longer than 30 minutes - The idea behind this stems from the cognitive overload theory. That is, students, especially in today's technology-focused society, tend to lose attention after shorter periods, when overloaded with new information (356 Labs 2021). We found that 30 minutes should be the maximum amount of time spent on one activity. Over two hours, we tried to include at least four activities to avoid losing the students' attention.

4. Give them something to bring home - Often, we associate memories with objects. The intent of handing out our 'Junior Certified' pins was that students would attach their pin to their backpack or some other belonging and remember the experience they had with us!

5. Network - Find out what others in Earth science outreach are doing. For example, there are nonprofit organizations in Canada involved in similar ventures (e.g. Mining Matters - https://miningmatters.ca/, MineralsEd - https://mineralsed.ca/, National EdGeo Program - https://www. edgeo.org/). There are also international efforts (e.g. Earth Learning Ideas - https://www.earthlearningidea.com/, SERC Carleton - https://serc.carleton.edu/index.html). All of these organizations and projects have put time and expertise into creating $\mathrm{K}-12$ geoscience lessons. Sharing resources, experience, and expertise is essential to advancing geoscience communication initiatives.

6. Get student volunteers - Many university students are interested in volunteering but may not have ample time to commit to off-campus activities. Having an outreach program at a university becomes convenient for students and gives them a fun break from their academic studies. Not only is it rewarding for volunteers, but it also improves their science communication skills. 
7. Create a website and social media page(s) - Nowadays, assume people don't know about you unless you're on the web. We were able to reach many teachers with our Facebook page and a simple $\$ 30$ Facebook advertisement. Social media is also a great way of keeping followers updated on your offerings, important dates, etc.

8. Provide fewer facts and have more fun - Our intent with outreach was not necessarily for students to remember all of the properties of a mineral. If they did, it was a bonus. The main goals were to make sure students had fun and gained interest in the science of the Earth. Making an activity seem fun is especially important as many of the events were aimed at elementary students.

9. Organization is vital - With the sheer number of things to remember during an outreach session, having an organized schedule and checklist was imperative. Supply lists ensured that every material necessary for each lesson was accounted for and located together in one place. A schedule including detailed steps for setup, the activities, and take-down was crucial to ensuring a smooth event. Organized plans also ensured that the program could be run by different people, which supports program flexibility.

\section{Benefits}

$\mathrm{K}-12$ students, their teachers as well as undergraduate and graduate volunteers all benefited from this program. $\mathrm{K}-12$ students benefited from seeing mineral, rock, and fossil specimens that they would not usually have access to in their classrooms. They also benefited by learning about geological processes from volunteers who actively learn about such topics in their degree programs. These volunteers may also act as young role models in geoscience to $\mathrm{K}-12$ students. The teachers benefited from this program since this is a free resource that they can use to supplement any classroom teaching they have done on the subject. Lastly, the U of S volunteers greatly benefited from this program as they can keep introductory geology information fresh and learn science communication, organizational, and leadership skills during the program.

\section{Future Opportunities in University Outreach}

Moving forward, university departments should set aside designated funding for community outreach initiatives and consider hiring science communicators to run programs like this. Organizing this program typically involved $\sim 4-8$ hours of volunteer work each week for the outreach coordinator. However, bringing a program to its full potential would easily require a full-time position. By hiring full-time employees with relevant training, departments could expect a research-guided approach to outreach initiatives, potentially resulting in 1) greater public interest of and trust in the geoscience industry; 2) increased enrollment in their geoscience program; and 3) meaningful engagement within local communities. In addition, science communication training would equip undergraduate and graduate students with the skills necessary for engaging with various audiences, including peers within their disciplines. This training has tremendous applications for geoscientists' future endeavors whether in industry, academia, or the public sector. Most importantly, having outreach programs accessible to communities and educators, who may not have the resources or geological background to discuss these subjects thoroughly, is an invaluable resource.

\section{ACKNOWLEDGEMENTS}

Many people and organizations made this outreach program so successful. First and foremost, the dedication of $\mathrm{U}$ of $\mathrm{S}$ undergraduate and graduate student volunteers was tremendous. On top of a busy university schedule of lectures, labs, and research, there were always volunteers to count on for showing up and bringing their best attitudes forward. The Canadian Geological Foundation, TakingITGlobal, Mining Matters, the Museum of Natural Sciences at U of S, and the Department of Geological Sciences at U of S are all thanked for their generous financial and in-kind support. Dave Lovelace from the University of Wisconsin-Madison Geology Museum is thanked for providing fossil casts and directions on making an improved fossil hands-on activity. Erica Bird, Laura Clinton, Terry Johanson, Tim Prokopiuk, and Kevin Ansdell are also thanked for their guidance and support during this program.

\section{REFERENCES}

Canadian Geological Foundation, 2021, About [website]. Retrieved from http://www.canadiangeologicalfoundation.org/?page_id=2. [Last accessed: 7/9/2021].

Government of Saskatchewan, 2021, Saskatchewan Curriculum [website]: Government of Saskatchewan Ministry of Education. Retrieved from https://www.edonline.sk.ca/webapps/moe-curriculum-BB5f208b6da4613/. [Last accessed: 8/9/2021].

Metcalfe, J., 2019, Comparing science communication theory with practice: An assessment and critique using Australian data: Public Understanding of Science, v. 28, p. 382-400, https://doi.org/10.1177/0963662518821022.

Reincke, C.M., Bredenoord, A.L., and van Mil, M.H.W., 2020, From deficit to dialogue in science communication: EMBO (European Molecular Biology Organization) Reports, v. 21, e51278, https://doi.org/10.15252/embr.202051278.

TakingITGlobal, 2021, \#RisingYouth: community service grants [website]: TakingITGlobal. Retrieved from: https://www.risingyouth.ca/. [Last accessed: 7/9/2021].

356 Labs, 2021, The cognitive load theory and your presentations [blog]: 356 Labs Agency, Sofia, Bulgaria. Retrieved from: https://356labs.com/blog/cognitiveload-theory-presentations/. [Last accessed: 11/22/2021].

University of Wyoming Geological Museum, 2021, WyoFossil Augmented Reality App [website]: University of Wyoming, Laramie, WY. Retrieved from: http://www.uwyo.edu/geomuseum/wyofossil/. [Last accessed: 7/9/2021].

Received August 2021

Accepted as revised November 2021 


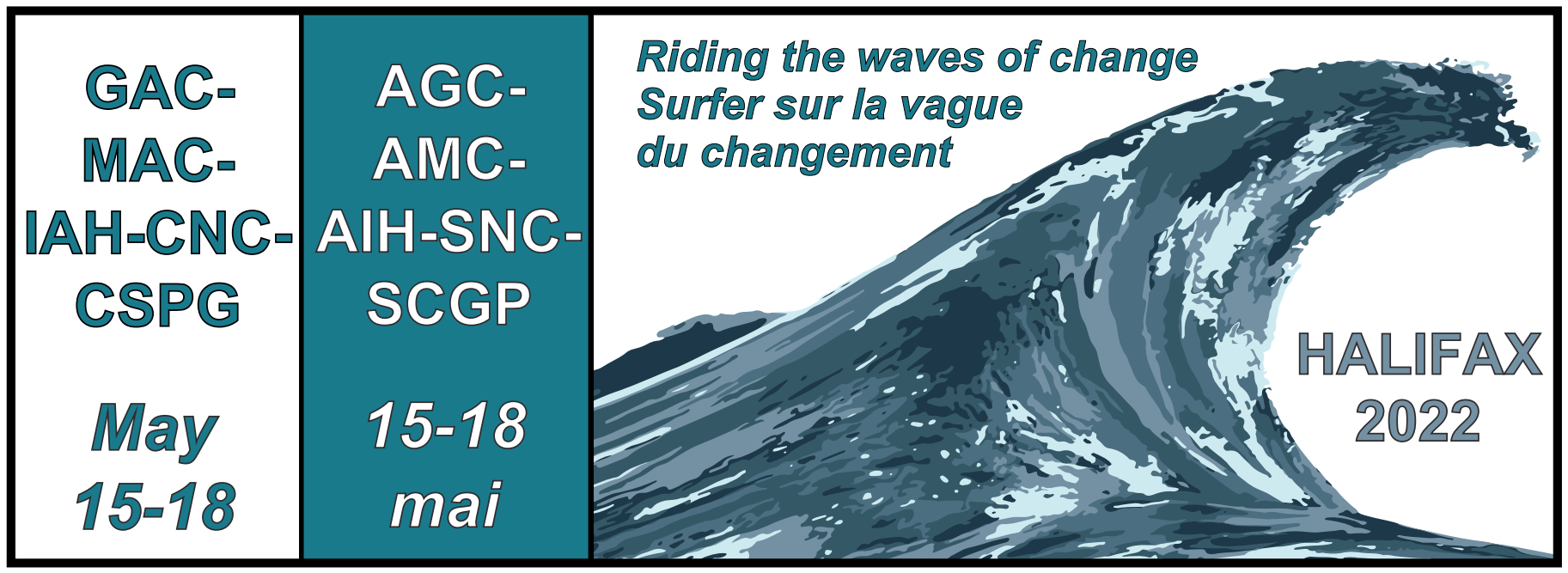

Abstract submission for the Halifax 2022 GAC-MAC-IAH-CNC-CSPG Joint Meeting is now open (December 1, 2021). The conference will be held in Halifax, Nova Scotia from May 15-18, 2022. Halifax 2022 is a joint meeting of the Geological Association of Canada (GAC), the Mineralogical Association of Canada (MAC), the International Association of Hydrogeologists - Canadian National Committee (IAH-CNC), and the Canadian Society of Petroleum Geologists (CSPG). The hosting society is the Atlantic Geoscience Society (AGS). Several other groups will also be providing content and coordinating with Halifax 2022. The overall theme for Halifax 2022 is "Riding the waves of change - Surfer sur la vague du changement", and certainly COVID-19 has made that theme even more appropriate than we anticipated! The conference will consist mainly of oral and poster contributions, arranged in thematic special sessions and symposia as well as in general topical sessions. https://halifax2022.atlanticgeosciencesociety.ca/technical-program/

The schedule will be organized to promote discussion among meeting participants. At this time, we are planning for a mostly in-person conference with the possibility of streaming or recorded access to oral sessions, and both in-person and virtual options for poster presentations. In addition to the 61 symposia, special sessions, and general sessions, there are 11 field trips and 8 short-courses.

Abstracts can be submitted through the conference website. Registration opens on January 1, 2022. https://halifax2022.atlanticgeosciencesociety.ca/abstract-submissions-and-registration/

Make sure to follow us on Facebook (G A C M A C Halifax), Twitter (@GACMAC2022), and Instagram (gacmac2022). See you all in Halifax! 